\title{
RadOSEAW SZTYber
}

Uniwersytet Zielonogórski

\section{SOWIZDRZALSKIE RYSY PORTRETU LISOWCZYKA W UTWORACH Z 1620 ROKU (RECEPCJA - DYLEMATY INTERPRETACYJNE)}

Anetce

Zagadnienie pomieszczone w tytule szkicu nie doczekało się osobnego i gruntowniejszego omówienia, choć pisarską (utrwaloną w prozie i wierszu) sylwetkę polskich zagończyków z początku XVII wieku rekonstruowano przy różnych okazjach i w rozmaitych aspektach. „Zabawki” spod znaku Marsa wymagały w ich obrazach piśmienniczych (relacjach osobistych jak pamiętniki, diariusze) bądź literackich raczej podniosłej nuty lub przynajmniej neutralnej, przecież z natury rzeczy ocierały się o kwestię życia i śmierci - jednostek, grup lub nawet narodu. Zarazem znamy utwory z gruntu humorystyczne, które podejmują tematykę militarną, aczkolwiek piętnują w ten sposób zjawiska, postawy, nie konkretnych ludzi. Główny bohater Wyprawy plebańskiej (Antologia 1986: 4-40) Albertus (podobnie jak w kontynuacjach tego dialogu) - kompromituje się w serii osobliwych poczynań czy wypowiadanych słów, a jego twórca, sięgając po parodię, krytykuje obowiązujące, lecz nieskuteczne regulacje. Zbliżone motywy zdecydowały o ostatecznym kształcie i treści Niepospolitego ruszenia abo gesiej wojnie Jana Dzwonowskiego (Antologia 1986: 299-306), w karykaturalny sposób szkicującego bezużyteczność zbieranej gromady szlacheckiej w obliczu ogniowej próby, a inspiracją do tego dwugłosu okazał się blamaż pospolitego ruszenia w czasie bitwy pod Chocimiem w 1621 roku (zob. np. Srogosz 2010: 140). Natomiast oba żywioły, mianowicie patos i zarazem ujęcia lekkie, żartobliwe zasilają tkankę Żywota kozaków lisowskich (Józef 2016: 46-65), co znacząco komplikuje przesłanie oraz jednoznaczny odbiór poematu. Poprzestańmy na tych zgrubnych i wstępnych konstatacjach; dodajmy wszakże, iż artykuł koncentruje się zwłaszcza na grupie pięciu tekstów: Liście o lisowczykach, Wierszach o lisowczykach, Żywocie kozaków lisowskich oraz młodszych, spisanych nieco później Liście do lisowczyków, a także $O$ lisowskich i konfederackich żotnierzach.

Lisowczycy, jak wiadomo, nie cieszyli się dobrą reputacją, nawet niekwestionowane i orężnie zaświadczone walory pułku nie stanowiły gwarancji czci i chwały. Członkowie oddziału okryli się niesławą zwłaszcza z powodu postawy w czasie pokoju. To ich obarczano winą za rozboje, gwałty, zabór mienia, morderstwa, a więc za czyny z kwalifikacją po prostu przestępczą, ściągające na odpowiedzialnych za nie „straceńców” co najmniej niechęć, by zmilczeć trwogę, jaką budzili wśród rodaków, a „słynęli z bezwzględnego traktowania ludności" cywilnej (Srogosz 2010: 114-115, 142). Przywrócenie dobrego imienia tego wojska mogło zatem zyskać rangę szczególnie palącej, nie cierpiącej zwłoki sprawy. Podjął się takiej misji kapelan kondotierów franciszkanin Wojciech Dembołęcki w Przewagach elearów polskich (2005) - utworze zróżnicowanym genologicznie (z elementami kroniki, pamiętnika i diariusza), w wymowie - apologii. Autor tej książki, wydanej w Poznaniu w 1633 roku, wiele zdań skreślił tak, by zatuszować skazy konterfektu jeźdźców wchodzących w skład najemniczych chorągwi, by zwyczajnie wybielić ich portret, zgodnie z zapotrzebowaniem samych zainteresowanych, skompromitowanych lisowczyków przemianowanych na dostojnych elearów, armię rzekomo samego Boga.

Jak istotne i zasadne było to zadanie, niech potwierdzi seria opinii tak dawniejszych, jak młodszych. Wojsko, wciąż oczekujące na zaległe zapłaty za wcześniejsze posługi żołnierskie (w konfrontacji z Moskwa), stanowiło poważne zagrożenie wewnątrz państwa. Projekt usunięcia lisowczyków z granic Rzeczypospolitej - by pozbyć się „,kup swawolnych” - przedkładał i przy współudziale otoczenia królewskiego wcielał w życie hetman wielki koronny Stanisław Żółkiewski (Wisner 1995: 68-74). Zamiar zrealizowano i lisowczycy 
w listopadzie 1619 roku rozpoczęli służbę na żołdzie Ferdynanda II; pozostawali do dyspozycji dowództwa monarchii Habsburgów, zagrożonej buntem wznieconym defenestracją praską z maja 1618. Relację o ich udziale w starciu pod Humiennem, tzw. pierwszej odsieczy wiedeńskiej, przedkłada wspomniany zakonnik, a całą akcję nazywa „odwabem rebelizantów od Wiednia”, usiłując w ten sposób równoważyć orzeczenia negatywne przy użyciu całej palety komplementów i ukazując „,wielkość przysługi elearów polskich cesarzowi” oraz „Panu Bogu” (Dembołęcki 2005: 175, 189-190).

Te czy inne pochlebne sformułowania Dembołęckiego o lisowczykach nie ustrzegły tych ostatnich od surowych osądów. „Kwiat i szumowina fantazji polskiej” - stwierdzał Władysław Łoziński, mówiąc o najemniczej formacji, a następnie dodawał: „,W ojczyźnie homo lissovianus był synonimem opryszka i wyrzutka społeczeństwa, którego gdy zabił infamis, w nagrodę za to powracał do czci” (Łoziński 1904: t. 1, 206), działo się tak, dlatego że „byli oni trudno uchwytni dla wymiaru sprawiedliwości”, a zanoszone na członków tej formacji skargi okazywały się najczęściej po prostu nieskuteczne (Srogosz 2010: 142). Niedawno Roman Krzywy (2016: 12) wypowiedział się zwięźle i dosadnie: „zapijaczona hałastra”. Nieco odmiennie położenie jednostki oddawał dziewiętnastowieczny historyk: „kędyż mieli się udać? Co przedsiębrać? Gdzie szukać przytułku i ochrony? Miecz katowski czekał ich w domu, miecz żołnierski szukał po wszystkich zakątkach" (Dzieduszycki 1844: t. 2, 275), następnie usprawiedliwiał: „była to [...] wina owych czasów jak ludzi, [...] ówczesnego wychowania, wyobrażeń, sposobu prowadzenia wojny i wzburzonych do dna namiętności, [...] pojedynczych osób lub pułków" (Dzieduszycki 1844: t. 2, 292). Jak w poglądzie Łozińskiego o tym wojsku, tak i u Maurycego Dzieduszyckiego ewidentnie wybija się ambiwalencja ostatecznej noty, pobrzmiewa i w obserwacji Władysława Magnuszewskiego (1978: 179): „,w każdym nawet najmniejszym archiwum krajowym, mimo destrukcyjnego działania czasu i wojen, możliwe jest natrafienie na jakieś przekazy świadczące o niechlubnej, a i zaszczytnej często działalności lisowczyków”. Celnie uwypuklił ją wreszcie i powieściopisarz:

szła tedy fama po Rzeczypospolitej, nie wiedzieć co bardziej głosząc: sławę czy osławę żołnierzy nieboszczyka pana Lisowskiego? W rzeczy zaś samej zasłużyli sobie oni tyleż na chwałę, co i na hańbę, że to będąc dzielnymi w boju we dwójnasób jak inne znaki, w trójnasób może więcej swawolili w czas pokojowy (Królikowski 1983: 8-9).

Utrwalał się stereotyp - jego ofiarą padł niedawno Jacek Komuda (2013: t. 3, 339) - zamknięty w formule „co hultaj to lisowczyk” (Co nowego 1903: 78), a obrazowo zarysował go czy raczej zilustrował Bohdan Królikowski w swojej prozie historycznej.

Kiedy zatem karczmarz brał pięścią przez łeb od zbrojnego męża, kiedy inni ciągnęli po wsiach barany z obór, świniaki z chlewów, a owsów koniom sypali jak ze swego - przeklinano lisowczyków. Gdy pijana czereda, miotając dla śmiechu pochodniami, zaprószy ogień w jakimś miasteczku - prawiono, że lisowczycy. Pohańbi żołnierz dziewkę - pewnie lisowczyk. Potrąci łyka na jarmarku, zajdzie drogę szlachcicowi - jużci nie kto inny, jeno lisowski straceniec (Królikowski 1983: 9).

Wszelkiej maści opryszków „łupiestwa obciążały lisowczyków” - pisał znawca (Ziembiński 2009: 71). Przysługiwały się tej niesławie wyczyny poszczególnych członków zbieranej gromady, niejaki ksiądz Stanisław Brzeziński (a przyjdzie jeszcze wspomnieć tego duchownego), ,psychopata”, ,początkowo w niezbyt skrupulatny sposób zarządzał szpitalem” w Bochni, ,potem wyruszył w świat z lisowczykami, by po powrocie stać się zabójcą niewinnego człowieka" (Czapliński 1966: 57). Jego imiennik, Łahodowski - znany z Przewag - przez lata prowadził otwartą wojnę z braćmi o schedę po ojcu. W jej wyniku został zamordowany w straszliwych okolicznościach. „Zażywał ten niecnota i brał nasze - wykrzykiwali zabójcy - my też będziem brać i zażywać jego" (Łoziński 1904: t. 2, 32). Dodajmy jeszcze, że bratobójcy, choć obwołano ich infamisami, uniknęli słusznej 
przecież kary. Nadto ów Łahodowski wsławił się „obrabowaniem posłańców królewskich” (Magnuszewski 1978: 181).

Jak już wspomniano, Dembołęcki włożył wiele wysiłku, by na kartach swojej relacji odbudować dobre imię lisowczyków; służyć temu celowi miało również zamieszczenie w Przewagach ,artykułów wojskowych”, swoistego kodeksu prawnego, uchwalonego przez koło generalne kondotierów, żeby oddział nie odbywał swojej służby „,bez szaty karności żołnierskiej” (Dembołęcki 2005: 249). Niemniej decyzja o włączeniu owego autentycznego dokumentu, choć perswazyjnie i propagandowo słuszna, niepostrzeżenie przyniosła skutek raczej niepożądany ze względu na specyfikę tegoż legislacyjnego aktu. Uderza w nim szczegółowość opisu, co przekłada się na możliwość odtworzenia rzeczywistego portretu najemników, a zwłaszcza jego pejoratywnych komponentów. W składających się z 31 punktów regulacjach w ponad ich połowie winnego spotkać miała najwyższa kara - „ma być gardłem karany”, a więc kodeks to bardzo surowy. Daje też całkiem miarodajny wgląd w patologiczną codzienność, obyczajowość towarzystwa spod elearskich chorągwi. Przytoczmy jeden ustęp, artykuł 29.

Kto by się ważył na wstyd wojskowy w ryńsztoku siedząc, pić abo w koszuli (a tym bardziej) nago na koniu biegać, abo na ulicy jawnie a z pijaństwa siedzieć i insze podobne temu hultajstwa płodzić, [...] jeżeli rotmistrz - 100 winy na potrzeby wojskowe ma - nie odchodząc od sądu - odliczyć i w kole swej chorągwie towarzystwo przepraszać za to, co jej wstyd uczynił (Dembołęcki 2005: 281).

Co ciekawe, znany jest przypadek potwierdzający zasadność przepisu wymierzonego właśnie w opilstwo. „Eksces w nieco innej wersji i w innych latach demonstrował, już w »cywilu« [...], ksiądz Brzeziński: »podniecony winem wybiegał w bieliźnie, bez butów i czapki, po nocy z szablą na ulicę, ścigając spokojnych przechodniów «" (Magnuszewski 1978: 157). Nawet o skłonnościach dewiacyjnych (ówcześnie na pewno tak postrzeganych) trafiają się symptomatyczne wzmianki, mieli bowiem ci żołnierze - według relacji naocznego świadka, Jerzego Wernera, pastora z Kowar - rabować odzież, „zwłaszcza płaszcze, płótno, zaś głowy ich zdobiły białe kobiece czapki”. Ukrócenie tych haniebnych praktyk postulował Stanisław Stroynowski, pułkownik oddziału, w zmodyfikowanym nieco i poszerzonym kodeksie z 1623 roku, ,gdyż takowe, prócz polskiego, stroje wstyd wojsku czynią i dla kilku wszytko wojsko za łupieżne poczytane bywa" (Magnuszewski 1978: 150). Oto w dużym skrócie, jak w świetle różnych wypisów jawią się ci „rycerze bez trwogi i honoru, bohaterowie i łotry zarazem" (Łoziński 1904, t. 1: 206). Henryk Wisner (1995: 102-133) nieprzypadkowo, aczkolwiek wymownie jeden z rozdziałów swojej monografii zatytułował Stawa i osława.

Niewątpliwie najgłośniejszy duszpasterz lisowczyków także wydatnie przyczynił się do takiej „renomy” oddziału, zresztą nie wyłącznie słowem, ale i czynami, ocierającymi się niekiedy po prostu o skandal. Okres bezpośredniego obcowania z wojskiem dał mu niepowtarzalną szansę pozbycia się, choćby na chwilę, palącego go habitu zakonnika (por. Magnuszewski 1976: 64), włożonego chyba przez pomyłkę, wskutek nalegań matki, która korzystając ze swoich koneksji rodzinnych pragnęła zabezpieczyć synowi przyszłość. Na co najmniej pół roku Dembołęcki przedzierzgnął się w lisowczyka, jak zapisał niechętny raczej kapelanowi Julian Bartoszewicz (1881: 97), „pół mnich, pół żołnierz” stwierdzał Dzieduszycki (1844: t. 2, 129). „Czuł się szlachcicem, imponowała mu wojaczka i życie świeckie” - notował z kolei Magnuszewski (1976: 64-65). „Nawykły do wojaczki i życia wędrownego, nie smakował już w cichym żywocie klasztornym. Wyrobił więc sobie komisarstwo jeneralne w zakonie, co pozwalało na ciągłe z klasztoru do klasztoru podróże” (Gloger 1900: 313). „Tonzury nie nosi, głowę po świecku goli, a twarz ma osypaną krostami" - pisano (Janczak 1906: 392). Donoszono nań, że podczas kapituły nie zatrzymywał się w konwencie, lecz w mieście, że miał osiem koni oraz służbę, że pozbawiał konwent jałmużny, że - jak kupiec - handlował, i że nikomu nie przedstawiał 
sprawozdań ze swojej działalności oraz posiadanego majątku (Bartoszewicz 1881: t. 2, 103; Kochańska 1956: 138-139). Nawet druk Przewag przebiegł z naruszeniem prawa (Wojciechowska 1927: 63-64; P. Buchwald-Pelcowa 1995: 71-73). Współczesny prozaik wreszcie wcale trafnie kwitował: Dembołęcki „w życiu prywatnym był osobowością zgoła nietuzinkową i jako żołnierz-mnich prowadził wesoły tryb życia, nie stroniąc od trunków oraz panien łatwego i lekkiego autoramentu. Jako członek towarzystwa powołanego w celu wykupywania jeńców od Turków zdefraudował - prawdopodobnie przepił, przehulał, przejadł [...] - pieniądze przeznaczone na uwolnienie więźniów z pohańskiej niewoli" (Komuda 2013: t. 3, 337-338).

W zarysowanym pokrótce kontekście decyzja o kreowaniu portretu lisowczyka z wykorzystaniem instrumentów typowych dla obrazów literackich prezentujących świat na opak wydaje się dość ryzykowna, a nawet cokolwiek zagadkowa, na pewno zaś zastanawiająca. W warsztacie twórców sowizdrzalskich znajdujemy przecież komizm, parodię, karykaturę, ironię, a to dzięki nim proponowane ujęcia rozmaitych zjawisk, z oczywistych względów dalekie od wzniosłości i powagi, ośmieszają opisywane fenomeny, gdyż takie $\mathrm{w}$ istocie cele przyświecały autorom hołdującym poetyce spod znaku odwracania wszystkiego kota ogonem (Grzeszczuk 1985; 1994). Tak dzieje się choćby we wspomnianych na wstępie Wyprawie plebańskiej czy Niepospolitym ruszeniu, by nie wykraczać poza krąg tekstów podejmujących tematykę wojenną czy właściwie raczej jej dotyczących. Nadto nieprzychylnie ukazano lisowczyka w innych utworach tego nurtu, a mowa o Zwróceniu Matyjasza z Podola (Polska komedia rybałtowska 1931: 542), natomiast dialog pt. Nędza z Bieda z Polski precz ida przedstawia zwłaszcza grabieżcze zakusy samozwańczego żołnierstwa:

[...] machlerze byli lisowczycy.

Półgroszki pochowali i monetę dobrą,

Wiele ich ma od tego komorę osobną.

Jako mogą ubogie tak bez ługu myją,

A kto może co zarwać, to po kątach kryją.

Panowie drą poddanych, żołnierze też łupią,

Tak się sami szkodują swą mądrością głupią (Nędza 1818: 22).

Kwestia kradzieży w przypadku lisowczyków, wolno powiedzieć, osiąga rangę swoistego „toposu”, o czym przekonuje nawiązujący do konwencji sowizdrzalskiej wiersz O lisowskich i konfederackich żotnierzach Olbrychta Karmanowskiego (Trepka 1963: 22-23; odpowiedzialność za sprawstwo zabytku obwarowano kilkoma zastrzeżeniamiZiembiński 2009: 70), a wymowa tego tekstu jest jednoznacznie krytyczna, nie tępi jej seria paradoksów - podobnych do przytoczonej dopiero co „mądrości głupiej”- ponieważ wybija się tu opinia o stosowaniu strategii perswazyjnej polegającej na bagatelizowaniu autentycznych przestępstw czy występków. Rzecz jasna, to negatywne orzeczenie - obnaża pozory zasadności literackich i nadto gołosłownych prób usprawiedliwienia niepożądanych praktyk, nie znajdują one bowiem żadnego oparcia ani w faktach, ani tym bardziej w sposobie konstruowania argumentacji obrończej. Krótko, o omawianym akurat krótkim wytworze talentu Karmanowskiego można zasadnie powiedzieć, iż to nie tylko nagana wymierzona w winnych, zdefiniowanych w tytule tej lapidarnej rymowanej wypowiedzi, lecz równocześnie i swoista recenzja, poddająca ocenie ruchy pióra tych, którzy postanowili wziąć w obronę lisowczyków, żeby wagę ich haniebnych czynów co najmniej osłabić.

Wolno wyrazić domysł, że wiersz-recenzja - a przynosi on „rejestr zwrotów, rozszyfrowujący ich właściwe znaczenie” (por. Ziembiński 2009: 70) - wcale bezpośrednio odnosi się do ogłoszonego drukiem w 1620 roku (Krzywy 2016: 46) Żywota kozaków lisowskich, gdzie w większej jego partii dominują chwyty umożliwiające przenicowanie 
chyba absolutnie wszystkich norm moralnych, prawie wszystkich, ponieważ zręcznie pominięto w tym tekście jedno szczególnie drażliwe wykroczenie, piętnujące ewidentną patologię; w artykułach elearskich otrzymała następującą deskrypcję: „kto by gwałt jakiejkolwiek białygłowie uczynił, a o to pozwany był, gardłem ma być karany" (Dembołęcki 2005: 281), aczkolwiek ten rodzaj przestępstwa znalazł jednak swoje zawoalowane odbicie w innych branych pod uwagę w tym szkicu lisowianach.

Reprymendy wyrażone w krytycznym epigramacie (wyjąwszy dostrzeżone zagadnienie oceny metody dowodzenia w Żywocie) skupiają się właściwie na komplecie obyczajowych przewinień żołnierskiej braci. Słowem, autor wyjątkowo zwięźle demaskował peryfrastycznie kamuflowane i pieczołowicie opakowywane w żart kolejne występki lisowczyków, a to nie zbiór „dowcipów płaskich, ciągniętych za włosy” (Nowak-Dłużewski 1971: 276-279), lecz ukazujący „zawadiactwo i barwne życie obozowe” (Badecki 1950: XXVII). Bez szczególnego trudu można pokusić się o skorelowanie odpowiednich fragmentów literackiego komentarza (zawierającego objaśnienia, podsumowania, syntezy) z serią „rozgadanych” passusów układanych na sowizdrzalską nutę. Oto kilka poglądowych zestawień.

\section{Żywot kozaków lisowskich}

Rogate syllogizmy stąd u pasa noszą, Obuchem perswadują, kiedy o co proszą. $[\ldots]$

Skoro się zaś rozwiedzie z swymi argumenty,

Poczujesz z ruski miesiąc, pójdzieć aże w pięty.

$[\ldots]$

Miłosierni jak trzeba, kiedy co obaczą

Nagiego, swoją suknią prędko nakryć raczą.

Co wszystko darmo sprawiają, a za nic nie ważą Pracej, gdy komu z łaski boki kijem mażą.

Pulsy zdrowym macają z uprzejmej miłości

Tak dobrze, że przez skórę namacają kości.

$[\ldots]$

A kiedy sie przeżegna który z nich pałaszem, Upadnie chłopu ręka abo głowa czasem.

$[\ldots]$

Desperaci okrutni, upiwszy się kradną.

Niechajże sie szanuje, w piciu zna dyjetę, Wino cebrem, miód konwią, kuflem akwawitę.

Wszystko przez zdrowie pełniąc, nic nie dbając o nie,

Nie tak prości mają być ludzie jako konie.

Ci sie do strzelby ćwiczą, bo kto dobrze mierzy

Konwią, ten nienagorzej i z łuku uderzy.

Gębą pić, czołem zaś bić to kozacka sprawa,

$[\ldots]$

Od medcu wzięła naprzód imię medycyna, W niebie ten rzadko będzie, kto nie pija wina.

[...]

Biesiady nie zepsują, po doktorsku żyją, Przed obiadem, nie jadłszy, siedmkroć sie upiją

Gdy którego do cerkwie nabożeństwo ruszy

Zamknionej, podkopa sie abo drzwi wykruszy.

Cuda okrutne robią, a między inszemi

Ślepe zamki umieją czynić widzącemi
O lisowskich i konfederackich żolnierzach

Oszukać mądrość, naukę w szalbierstwo odmienić.

Podejść w czem śmieszną sztuką i figlem bez sromu.

Despekt uczynić, dzielność to sobie mianując.

Pijaństwo humanitas, a wszeteczne słowa Dworstwem zowią [...].

Skrzynią wyłupać, sprawność - dostać czego w domu;

Wziąć co, a nie zapłacić, w tem wstydu nie czując. 
Nawiasem mówiąc, ogląd wiersza O lisowskich i konfederackich żotnierzach pozwala uchwycić w nim zabiegi ornamentacyjne, jakie wnikliwie charakteryzował Janusz Ziembiński - przykłady zwłaszcza aliteracji oraz ciągów repet, stanowiących, przekonywał badacz, ulubione środki wyrazu artystycznego (wraz z innymi) Karmanowskiego (Ziembiński 2009: 69). Poddana analizie „,inwektywa” operuje bowiem zbliżonymi chwytami; zabiegi te, splecione ze sobą, najlepiej widać w sposobie organizacji wypowiedzi zasadzającej się na wyróżnieniu wybranych form czasownikowych z ekspozycją obecnego w nich (w identycznej, tj. inicjalnej pozycji) prefiksu „na” i jednakowej końcówki fleksyjnej - efekt reguł językowych rządzących polszczyzną, niemniej dzięki temu utwór zyskuje niekiedy dodatkowo rym wewnętrzny (obok dubletów rymowych w klauzuli), niewyszukany, bo gramatyczny. A zatem: „nastali, / [...] nadali. / Nazwali”, nadto jeszcze i „najedzie”. Jest i spory zespół bezokoliczników („Ukraść [...], wydrzeć [...] mienić. / Oszukać [...] odmienić. / Podejść / [...], wyłupać, [...] dostać [...]; / Wziąć [...] zapłacić") oraz imiesłowów (,gładząc, / [...] czując. / [...] mianując”); można zaobserwować również nieprzypadkowy dobór grupy rzeczowników w mianowniku: „mądrość, [...] / sprawność [...], / dzielność". Widać zarazem tryptyki. I wszystko to na przestrzeni ledwie dwunastu wersów. Paralelizm syntaktyczny, czasem skontaminowany z semantycznym (np. ukraść, wydrzeć, wyłupać, wziąć - to eufemizm), góruje nad innymi formami ekspresji, a właściwość ta być może zbliża do uprawdopodobnienia hipotezy, iż tekst ów wyszedł spod pióra autora Listu do lisowczyków, innego tekstu przypisywanego Karmanowskiemu (Ziembiński 2009: 59-77), o którym przyjdzie jeszcze powiedzieć, gdyż - jak i wiersz-recenzja - został zredagowany nie bez ewidentnych i nieuświadamianych raczej dotąd odwołań literackich. W rezultacie przybywa cech wspólnych, łączących oba drobiazgi wspomnianego właśnie Listu oraz O lisowskich i konfederackich żołnierzach.

Wróćmy jednak do Żywota, choć z pominięciem pochylania się nad poematem, gdyż otrzymał już gruntowniejsze opisy (Sztyber 2012: 7-25), w tym polemiczne (Krzywy 2016: 5-39; Sztyber 2017: 320-337); wszakże jedna kwestia, najważniejsza chyba, powróci, a dotyczy przesłania utworu - niejednoznacznego i w pewnym stopniu w rozpoznaniach badawczych kontrowersyjnego, gdy traktować wszystkie segmenty utworu kompleksowo, przecież są diametralnie różnoimienne w tonacji, a mowa o mariażu nieznośnie lekkich słów (na temat przestępstw) formułowanych na modłę sowizdrzalską $\mathrm{z}$ autentycznie podniosłą nutą, uruchomioną, by złożyć hołd zmarłemu wskutek odniesionych w boju ran pierwszemu pułkownikowi oddziału i jego założycielowi Aleksandrowi Józefowi. Zajrzyjmy wreszcie do zabytku:

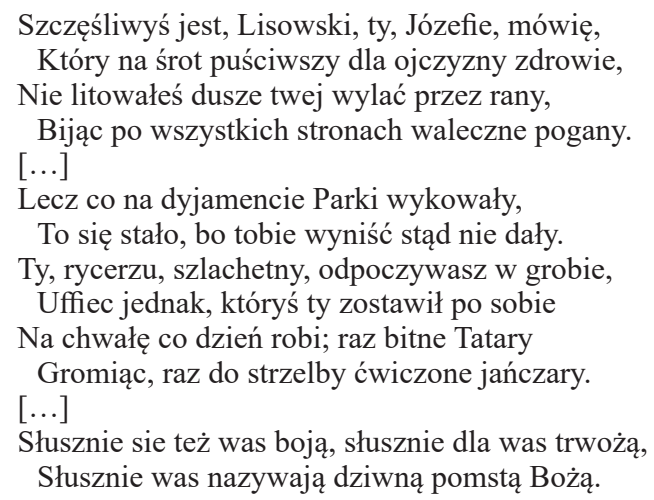

Wprawdzie również i w tej części, otwartej śródtytułem Potyczki kozaków lisowskich, trafia się leksyka z innego, obcego patosowi rejestru języka - do głosu dochodzi słownictwo obraźliwe, ale nie tylko (,bledysyny”, ,guzy”, „Melanknechtowa [...] wiara”, 
„lutrowie”, „gęby”), a nawet całe frazy „w stylu niskim” (Nowak-Dłużewski 1971: 276), m.in. „niejeden Czech mdleje / Dla gorąca, kiedy go futro lisie grzeje”, „Wyście lutrom do nieba porobili mosty, / Obudziwszy pokutę i wskrzesiwszy posty. / Wyście srogim bluźniercom zatykali gęby, / Że leciały na ziemię z nich jako grad zęby", co poniekąd burzy podniosły styl ustępu - zdradzająca pokrewieństwo z dorobkiem polskich sowizdrzałów i wcześniejszymi partiami Żywota (Nowak-Dłużewski 1971: 277), niemniej nie sposób wyeliminować oczywistych wrażeń lekturowych, jakie można odnieść na podstawie dopiero co przytoczonego obszernego wyimku, bliższego poezji heroicznej, opiewającej dzieła i czyny wybitnych bohaterów wojennych, w naszym przypadku ,wielkiej postaci Lisowskiego" (Nowak-Dłużewski 1971: 276). A koncept ukazania okoliczności zgonu (zarazem konkretnych przyczyn i wręcz fizjologicznych objawów oddanych z lirycznym polotem) twórcy samozwańczej formacji zasługuje na najwyższe noty. Ważną rolę odgrywa wzmianka o schedzie po sławnym „wojenniku”, czyli uformowanym przezeń wojowniczym hufcu, godnym uznania ze względu na swoje osiągnięcia na polu bitewnym, a spory ich rejestr w skrócie przynosi Żywot.

Stąd też i rozdźwięk w interpretacji zasadniczej wymowy poematu, gdy szacować wszystkie jego człony en bloc. Może to niekwestionowane zasługi militarne elearskiej braci winny rekompensować ich niesforność i niesubordynację. Przekaz Żywota, będącego utworem niewątpliwie należącym do kolekcji apologetycznych lisowianów, bezsprzecznie promuje dokonania zbieranych żołnierzy najemniczych, jest tym ostatnim przychylny, na co wskazuje niejako gradacyjna kompozycja całości i jej kierunek - od komizmu poprzez (nieco stonowany) patos aż po oszczędną w słowa, po żołniersku powściągliwą, a przez to neutralną dysputę dwóch doświadczonych kozackich wojaków - Iwana i Kiwajły. Chyba więc znajduje uzasadnienie zdanie J. Nowaka-Dłużewskiego, iż apoteoza Lisowskiego w tym zabytku jest najważniejsza. Tylko w ten ewentualnie sposób udaje się usprawiedliwić sowizdrzalski ryt tego niezwykle ciekawego, acz powikłanego utworu. Jakoby hołdującemu zasadzie, że zwycięzcy nie podlegają sądom ani też nie pyta się ich o zdanie, a może inna prawidłowość podyktowała takie rozstrzygnięcie - de mortuis nil nisi bene lub de mortuis aut bene aut nihil. W końcu zręcznie przemilczano choćby banicję Lisowskiego (Wisner 1995: 21-27).

Rozterki czytelników Żywota wydają się zrozumiałe; może zatem poemat nie jest satyrą inwersyjną ani panegirykiem, lecz „,bezstronną i [...] sprawiedliwą satyrą”, pisał Juliusz Nowak-Dłużewski (1971: 279), powołując się na słowa Karola Badeckiego (1950: XXVII), który zauważył, że tekst ten przynosi „bezstronny i sprawiedliwy sąd o lisowczykach. [Autor] ocenił tych groźnych [...] bojowników nie w sposób panegiryczny, ale wyrażając się z pochwałami o ich wojennych potyczkach, zaatakował z dowcipem i ironią »ćwiczenia«, »prawa« i »obyczaje« tego nieujętego dyscypliną żołdactwa". Może zatem kluczem do odpowiedniego odczytania utworu jest po prostu zawarta w nim prawda ujmowana stosownie, raz żartobliwie i prześmiewczo, a drugi poważnie - dająca sposobność zapoznania się z blaskami i cieniami całokształtu bytu lisowskich kozaków, dzięki czemu uwarunkowania utworu w jego wszystkich warstwach uwydatniają zarówno strony pozytywne, jak i negatywne członków pułku bądź całej jednostki wojskowej. Czy jednak ta adekwatność, poetycka „rzetelność” w portretowaniu oddziału istotnie przysługiwała się propagandzie na rzecz odbudowania dobrego imienia lisowczyków? Niekoniecznie, skoro już pisana mową wiązaną reakcja na postawę „lisowskich i konfederackich żołnierzy" celnie demaskowała obłudny charakter przynajmniej części Żywota.

Nieco inaczej rzecz się ma z parą powiązanych ze sobą zabytków, mianowicie z Listem o lisowczykach oraz tzw. Wierszami o lisowczykach (Sztyber 2011: 212-249). Te ostatnie przetrwały w rękopisie i są zmienionym, nadto rozszerzonym wariantem ogłoszonego drukiem Listu (Magnuszewski 1962: 58). Rozwiązania atrybucyjne dla obu tekstów i tym razem mają charakter hipotetyczny, oparte są bowiem na poszlakowym 
dowodzie, a łączą je z nazwiskiem Dembołęckiego. Obraz bohaterów tytułowych rymowanych epistoł, jaki się z nich wyłania, jest co najmniej specyficzny, zwłaszcza że bez wahania należy te literackie orzeczenia zaliczyć do grupy pochwalnych lisowianów.

Kreacja głównej postaci Listu oraz Wierszy wydaje się oryginalna, zestaw epitetów dość jednoznacznie klaruje, z kim mamy do czynienia - głupi, szpetny. Podobnie z rzeczownikami, mówią wprost: skurwysyn, diabeł, wilk, wrona, maklerzy (jak w dialogu pt. Nędza z Bieda z Polski precz ida). Wartość charakteryzowanego żołnierza określa się krótko - „szeląg nie stoi”, ponieważ przedkłada ponoć czerwone złote nad chleb; trafia się i życzenie - niechaj szaleją, a gdy się popiją, oby się nawzajem wybili. To rysy wydobyte jedynie z Listu o lisowczykach. Więcej informacji przynoszą obszerniejsze Wiersze, w których kondotierski wojak jawi się jako wielki lis - jak czwarta część świata. Głowa też ogromna, jak czeska ziemia, straszne oczy osiągnęły więc rozmiar jezior. Gdy jutro krzyknął, słychać było wczoraj. Miał zębów na gębie ze sto tysięcy i jak dziewięć miesięcy długi ogon, a zatem i wciąż nienasycony apetyt. Nogi - o dziwo - od brzucha do ziemi. Ten straszny lis dał początek istnym diabłom, co noszą tylko dziwną czuprynę, pamiątkę ogona, którym szczyciła się ich matka. Bitewne rekwizyty towarzyszące lisowczykom również wydają się niezbyt udane; jakby niewydarzony ten sprzęt wojenny: „krzywy żelaz” (szabla) i krzywy kawałek drewna spięty sznurkiem (łuk), bez zbroi, a zamiast postawnego rumaka - chuda kobyła, szkapa marna z niewielkim, twardym siodłem. Nierzadko przedmioty te czy właściwości niekarnych „towarzyszów” zostały rozmaicie skonfrontowane z ich niemieckimi odpowiednikami. Niemiec, gdyby znalazł polską szablę, pogardziłby takim orężem; lichy koń kozaka w niczym nie przypomina tłustego freza; lisowczyk obchodzi się bez pluder, nogi okrywa „rękawami”, wąskimi spodniami itd.

Nieco korzystniej wypada lisowczyk w ujęciu dynamicznym, w akcji. Oto bowiem lichemu koniowi zagończyka nie są straszne żadne przeszkody. Wspomnianą już kulbakę autor konfrontuje z siodłem wroga i przekonuje, że jest zbyt skromne, by zmieścić na nim choćby pół niemieckiej dupy, a na dodatek nie można się do niego przyśrubować, bo to nie krzesło (jak u wroga). Jazda wierzchem też zadziwia; pozycja jeźdźca wciąż się zmienia - raz pokłada się na szyi zwierzęcia, to znów sunie bliżej ogona, niekiedy widać go w połowie, ponieważ zwiesza się z tułowia konia na oba boki, w efekcie Niemiec nie może rozeznać, ilu to żołnierzy polskiej jazdy, co gorsza - trudno celować w tak zwielokrotnionego wroga. Może więcej sympatii powinien wzbudzić opis pojedynku lisowczyka z niejakim Hanusem, przecież skończył się triumfem Polaka, choć bez drastycznych scen się nie obeszło. Zrelacjonujmy pokrótce tę potyczkę. Do starcia wyszedł odważnie ów Hanus, strzelił w kierunku przeciwnika, ale bo ten w ciągłym ruchu, kula więc minęła cel, w rewanżu lisowczyk strzałą zdołał wybić prawe oko rywalowi. Rozgniewał się Hanus i wyrwał strzałę razem z mózgiem, chciał łucznika pchnąć szpadą, lecz nie zdążył, przyjął cios w gębę, jeszcze jedno takie cięcie, a batalia skończyłaby się śmiercią rajtara. Jednak lisowczyk zaniechał ataku i podszedł do swojej ofiary, aby dobrać się do kosztowności, łupi nieboraka, a ten woła „fryd, fryd” (wolność, wolność), dam ci brot (chleb), lecz napastnik źle rozumiał i zgodził się na prośbę - wrył więc kamień „fryd” (tj. w rzyć). Hanus zapewniał: dam ci brot (chleb) i kieszeń (pieniądze), w odpowiedzi zaś usłyszał - ty sam będziesz „gofen kryzen” (tj. gówno gryzł). Hanus prosił Polaka o wolność, ale i tym razem ten ostatni nie pojął słów ofiary, zrezygnowany Niemiec plunął więc duszą w pludry (tj. wyzionął ducha). Zawieśmy głos na tym skatologicznym finale.

Z konieczności poniekąd parafrazowane fragmenty utworów przynoszą portret lisowczyka niekoniecznie pozytywny, choć może wygrana w batalii z Hanusem przedstawia zwycięzcę w lepszym nieco świetle. Komedia dialogowych pomyłek, a właściwie nieporozumień, ubarwia rodzajową scenkę, niewolną jednak od akcentów znanych z innych tekstów, bo i w tym opisie skłonność do grabieży trudno przeoczyć. Finał boju, choć szczęśliwy dla najemnika, odtwarza okoliczności towarzyszące śmierci pobitego, ale to 
ciężki raczej żart, grubiański, wręcz brutalny i może na miejscu jedynie ze względu na poetykę utworu. Dodajmy, że - jak czytamy w Wierszach - za tak odmalowanym lisowczykiem tęskniły ponoć „niebogi dzieweczki”, niemieckie, rzecz jasna.

Jakiekolwiek nagany, kalumnie czy uwagi krytyczne o lisowczykach w Liście i Wierszach rekompensuje, równoważy sytuacja komunikacyjna, w jakiej padają strawestowane słowa. Aspekt ten celowo przemilczano, zresztą i dlatego że pierwotna szata językowa obu zabytków zniechęca do lektury, poważnie ją komplikuje, niemniej stanowi integralny i rzeczywiście ważny element formułowanych przekazów. Mówiąc najkrócej - kompromituje nadawcę, bo i mowa winna wyróżniać „odszczepieńca” (Tazbir 1986: 153-154), a tym samym i promowane treści, dlatego ocena lisowskiego żołnierza ostatecznie nie powinna wypaść negatywnie. Zbigniew Nowak tłumaczył istotę językowego żartu uobecnionego w Liście następująco:

w zakresie fonetyki parodia polega przede wszystkim na zastępowaniu głosek dźwięcznych głoskami bezdźwięcznymi, np.: efanjelików, ferbi, księdzofi, Mydlarzofi, parzo (barzo), tafno (dawno), ropić (robić), pędą (będą), rozkniewal, przyknal, tobrze. Często występuje wymiana 'ch' na ' $k$ ', np.: wyjekal, kleb, klop, klopcy, korągief; ' '’' na 'l', np.: glupi, zly, skryl, 'c' na 'cz', np.: czury, mocznego. Występuje brak zmiękczeń, np.: powem, cierpem, pes, pecze, ne, pernat, neba, nech, prosem. Trzeba przyznać, że w zakresie fonetyki autor dobrze podpatrzył niemiecką i czeską wymowę polskich wyrazów (Nowak 1968: 118).

Nie inną sytuację obserwujemy w Wierszach. Obu epistołom nadano formę fingowanych listów, są to skargi na lisowczyków adresowane do przywódcy reformacyjnego Marcina Lutra i wysłane przez wyznawców jego nauk religijnych - najpierw biada nad losem swoim i własnej trzody Habspert Nikiel (List), potem niejaki X Faclaw (Wiersze). Niezbyt wyrafinowany dowcip (może nawet makabryczny raczej) towarzyszy również samemu momentowi nadania przesyłki. Rozochoceni jakąś szaloną zabawą lisowczycy obiektem swoich drwin postanowili uczynić pojmanego przypadkiem pastora, któremu do bufiastych spodni - w pludry i tym razem - wsypali proch, by wysadzić w powietrze „ministra”, tym samym nadarzyła się okazja do nadania listu, skorzystali z niej wierni protestanckiego księdza i do materiału wybuchowego dorzucili spisane naprędce gorzkie żale. Tak oto skutecznie miały trafić do nieżyjącego już w chwili tłoczenia broszury Lutra. Nawiasem mówiąc, autor zadbał o „uwiarygodnienie” tego zdarzenia, ponieważ zapewniał, iż treść korespondencji została przełożona „na angielskiego, francuskiego, polskiego języka”, ,z swego glowa”, tj. rzeczonego Nikla. Jak z kolei wynika z Wierszy, miejsce pośmiertnego spoczynku adresata tej wiadomości nie jest pewne - „czy w niebie, czy w piekle, czy w obu naraz" rezyduje - a wątpliwość tego rodzaju zyskuje wydźwięk kalumnii. Od tak właśnie usytuowanego w zaświatowej rzeczywistości „mątrego szlofieka, Pana Doktora Martyna" nadawcy listów oczekiwali pomocy, mianowicie wybawienia ich samych oraz swoich wiernych od plagi lisowskiej. Nieskuteczność zanoszonych błagań dotkliwie odczuł X Faclaw, ponieważ został niejako zmuszony do sporządzenia kolejnego listu - toteż i w liczbie próśb kierowanych do Lutra (nie przynoszących spodziewanych rezultatów) należy upatrywać siły perswazyjnej paszkwilanckiego pomysłu.

Dodajmy, że najbardziej eksploatowanym motywem w obu tekstach są wspomniane pludry; bezceremonialne szyderstwo z tej części garderoby, rzekomo należącej niegdyś do Lutra, czyni z niej nawet świętą chorągiew, jakoby swoistą - a to paradoks - relikwię protestancką, co jeszcze bardziej wyostrza wymowę inwektywy. Frekwencja rzeczownika nie jest niska, w Liście występuje pięć razy, w obszerniejszych zaś Wierszach dwukrotnie częściej, a sprawę podnosimy, by zilustrować poziom komponowanego na sowizdrzalską modłę komizmu. Wydaje się niskich lotów i jest obliczony na odbiorcę, którego mogłyby zadowolić tanie, przejaskrawione chwyty literackiej ekspresji. Oczywiście w obu tekstach natrafimy na znacznie więcej żartów tej kategorii - czy istotnie budziły śmiech? 
Przywołajmy jeszcze jeden koncept; Nikiel utyskuje, że od chwili pojawienia się lisowczyków ustąpiły „tłuste piątki”, a myśl także eksponowano w Żywocie - wskutek działań jego bohaterów tytułowych przywrócono post i pokutę dla protestantów. W każdym razie w ujęciu tym choćby grabież samozwańczych oddziałów uzyskała usprawiedliwienie, a lisowczycy mogliby liczyć na rozgrzeszenie za każde chyba przewinienie, ponieważ ich ofiarami byli przeciwnicy religijni, przynajmniej tak to ukazano w omawianych zabytkach. Zasługi więc dla katolicyzmu miałyby być powodem do wybaczenia i odpuszczenia wszelkich win, jak wolno na tej podstawie zrekonstruować zastosowaną logikę dowodzenia. Podobnie mechanizm ów identyfikował J. Ziembiński (2009: 65), choć nie sposób dać się zwieść tendencyjnym uzurpacjom. Doprecyzujmy akurat wypowiedziane spostrzeżenie, domaga się bowiem uściślenia ze względu na uwarunkowania tekstowe łącznie Listu i Wierszy (nadawca, odbiorca, szata językowa) oraz samą treść w jej partiach ogólniejszych. Nikiel otwiera utwór symptomatycznie (tym razem cytaty poglądowo otrzymały oryginalne brzmienie):

Posłuchajcie krzywda co powem, Jako cierpem chrzecijanofie, Od skurwysyn Lisowczykofie.

A zwrot to bezpośredni do Lutra, wtóruje temu wyznaniu Faclaw -

Niech faszego ucha naszey krzywdy slicha

Niech twoy oka widzi iak lutrofie zdycha

O iak fiele cierpim twoy Chrzescianofie

Od okrutny Polski ten Lisofczykofie

Wniosek wydaje się prosty. Czytelnik - pojmowany stereotypowo jako Polak-katolik - znalazł się programowo w pozycji świadka, obserwującego prymitywnie formułowane (niemiłosiernie kaleczoną polszczyzną), niejako podsłuchane (niejako, bo przecież dostępne w translacji) narzekania na cierpienie i położenie przeciwników wyznaniowych, które są skutkiem militarnych akcji lisowczyków, wysłanych - jeśli nie wygnanych w następstwie nalegań i rozkazów hetmana Stanisława Żółkiewskiego (Wisner 1995: 68-74), o czym również mowa w Wierszach - do krajów cesarskich, gdzie uczestniczyli w gaszeniu pożaru rebelii wszczętej defenestracją praską. Słowem, oba rymowane utwory miałyby nakłonić ich lektorów do dumy z przysług elearskiej braci w wojnie trzydziestoletniej, nadto zawartość pary listów miałaby stać się dowodem... niewinności lisowczyków, gdyż zadawane przez tych ostatnich męki dotykają przecież obcych, co wymowne. Pokrętna to logika, zważywszy nieomal przysłowiową (to oczywiście przesada) tolerancję wyznaniową ówczesnej Rzeczypospolitej, świadomość chrześcijańskiej wspólnoty (Ekes 2010: 215-216), może i wrażliwość społeczną, postulat miłosierdzia czy jedno z najważniejszych przykazań - miłości bliźniego. Mocno obłudne, aczkolwiek relacje społeczne na wielu płaszczyznach, jak wiadomo, dalekie były od ideału, więc i zajadłe spory na tle religijnym, nie respektujące reguł pożądanej kurtuazji, nie mogą dziwić (Hawrysz 2012: 230-279). List cieszył się jednak wzięciem, tłoczono go dwukrotnie w 1620 roku (Nowak 1968: 404-406), choć i później - w czwartej i piątej dekadzie XVII w. (Nowak 1968: 406; Magnuszewski 1962: 58). Czy to dowód popularności druku w obiegu czytelniczym, czy też może efekt gorliwych zabiegów propagandy na rzecz lisowczyków? Publikowano przecież inne broszury utrzymane w tym właśnie duchu (Magnuszewski 1972: 226). Są jednak fakty historyczne innej natury. Najpewniej wskutek niezadowolenia sztabu generalnego monarchii habsburskiej jeszcze na początku lutego 1620 roku lisowczycy uchwalili swój pierwszy kodeks wojskowy (Dembołęcki 2005: 192), a gdy wracali z państw Rzeszy pod koniec roku 1622 najpierw Ślązacy, a następnie Wielkopolanie zgotowali im zbrojne 
przywitanie (Dembołęcki 2005: 339-348). Z jakich powodów, nietrudno się domyślić, a wracali przecież bohaterowie opisywani m.in. w Żywocie, Liście oraz Wierszach.

Zmierzając do finału szkicu, trzeba pochylić się nad kolejnym, wspomnianym już drobiazgiem literackim. Wnikliwie badający List do lisowczyków (bo o te dwadzieścia wersów chodzi) J. Ziembiński podkreślał nade wszystko pomieszczony w nim autorski werdykt wydany na postawę członków samozwańczych hufców (choć to studium wieloaspektowe). Postawił też intrygujące pytanie: „może sięgnięcie po podobny tytuł przez autora Listu do lisowczyków wskazywałoby na jego kontakt z literackimi płodami apologetów słynnego oddziału?" (Ziembiński 2009: 66, przyp. 28) I odpowiedź musi być twierdząca, ponieważ nie tylko wypowiedzi inicjalne łączą na pierwszy rzut oka zabytki. Są inne wyraziste ślady. Wstępne jego fragmenty wydają się czytelną aluzją do Wierszy, ustalając alternatywną i polemicznie objaśniającą wizję pochodzenia lisowczyków, aczkolwiek temat doszedł do głosu (w odmiennej transpozycji) także w Żywocie.

Wiersze o lisowczykach

Iest Go tam na Polski iama głębokiego w którym się urozil liszka tak fielkiego.
List do lisowczyków (Poeci 1977: 216)

Nie w Indyjach, nie w krajach zamorskich zrodzeni, Ni w lesie ze zwirzęty, choć Lismi rzeczeni.

Inna reminiscencja zaznacza się poprzez repetę dwu pozostających w bezpośrednim sąsiedztwie rzeczowników użytych w identycznej formie deklinacyjnej: „Fkomorze, Foborze". W Liście do lisowczyków słowa te - w powtórzonym porządku - spinają rymem jeden z dystychów. Przypadkowość takiej organizacji klauzuli wyklucza jednakowy kontekst, w obu bowiem zabytkach w odpowiednich miejscach uwypukla się akurat grabieżczy zapał żołnierzy.

Wiersze o lisowczykach

Gdy takofych ludziof Hetman Z Polski fygnal Musi nic nie mieć chłopek w swej własnej komorze, Fnet go fszytki tiabel na Nas Sląski przygnal To go fnet okrzyknąl az nic niezostalo

Fkomorze Foborze ytez się dostalo.

\section{List do lisowczyków}

Wrażenie oczywistych paralel, może nawet w sposób zamierzony eksponowanych, wzmacnia ewidentny kryptocytat. Bezsprzecznie inspiracji Listem o lisowczykach bądź Wierszami wypowiedź przypisywana Karmanowskiemu zawdzięcza włączona do niej fraza „Bo ciurowie wynajdą, by schował i w ziemię”, którą udaje się zestawić z parą dwuwersów: „Byś pod ziemia skrył i pod skóra, / Pefnie najdzie skurwysyn czura” (List o lisowczykach), „Bys ty skryl pod Siemia albo y pod skury / Przeciesz go fynaydzie ten skurwasyn ciury" (Wiersze). Kolejna linijka tekstu jako żywo przypomina refleksję Listu o lisowczykach: „Ale jaki fisieć slugowie / Tak i pan - właśni hultajofie!”, gdyż w wierszu późniejszym czytamy: „Ba, i sami panowie, wszytko to złe plemię”. W świetle zarysowanych zbliżeń nie dziwi utożsamienie ,popisanych”, tj. oficjalnie przyjętych w szeregi pułku „towarzyszów” z ich posługaczami obozowymi, zwłaszcza że mowa o wierszu połowicznie oryginalnym. Profetyczny charakter wieńczących List do lisowczyków słów - „Do piekła będziesz posłan na wieczne stracenie” - uznać z kolei wolno za nawiązanie do Żywota, m.in. zapowiadającego zaświatowy los kozaków - „Przestępcom naznaczona po śmierci pokuta”, a to konsekwencja zawarcia osobliwego „sojuszu”, „Ażeby lepszy pokój aż do śmierci mieli, / Z piekłem wrzącym przymierze na dziesięć lat wzięli” (Żywot). Rzecz jasna, w tym ostatnim przytoczeniu dominuje ujęcie żartobliwe, przewrotne rozumienie konieczności zadośćuczynienia za grzechy jeszcze za życia (konieczności odsuniętej na potem, na... święty nigdy, by posłużyć się kolokwializmem), natomiast w literackim jego pokłosiu słychać nutę troski, żalu z powodu zmarnowanych szans, a przede 
wszystkim win, które niechybnie zostaną nagrodzone... karą po wsze czasy wskutek werdyktu, jaki zapadnie ,przed srogim i strasznym sądem Bożym”.

List do lisowczyków właśnie wskutek obecnych w nim aluzji (rozmaicie manifestowanych) do apologetycznych lisowianów jawi się jako kolejny wiersz-recenzja, taksujący stronniczo pochwalne insynuacje wcześniejszych orzeczeń, mających na celu przywrócenie zachwianej pozycji kondotierskiego oddziału w opinii publicznej. Tak pojmowana koncepcja dopiero co wymienionego z tytułu utworu oraz O lisowskich $i$ konfederackich żołnierzach zbliża do siebie te teksty (nawet miara wersowa je łączy, bo to kolejna część wspólna - oba są trzynastozgłoskowcami), gdyż zrodziły je podobne okoliczności twórczej roboty - należy je wiązać z wolą reakcji w formie literackiego sprzeciwu wobec ewidentnego rozdźwięku między dostrzeżonym pochlebstwem - jakkolwiek ujętym (bo i na sowizdrzalską nutę) - a prawdziwą postawą członków pułku z osobna bądź w „kupach swawolnych”.

Zespół omówionych zagadnień z uprzywilejowaniem pięciu tekstów, z których dwa kojarzone są z nazwiskiem Karmanowskiego, nie wydają się błahe, ponieważ dowodzą istnienia na gorąco prowadzonej polemiki, koncentrującej się na ocenie lisowczyków. Przychylne - mówiąc najoględniej - tym ostatnim utwory propagandowe zweryfikowała rzeczywistość polityczno-sądowa, skazując „rycerzy bez trwogi i honoru” na zasłużoną banicję. Nie zapobiegła surowemu wyrokowi przesadna, bezkrytyczna nieomal apoteoza wojska (nie bez pewnych skaz mimowolnie i jakby przypadkowo utrwalonych) w Przewagach (Sztyber 2005: 231-240) ani tym bardziej szkicowany sowizdrzalskim piórem jego obraz, zachowany w Liście oraz Wierszach o lisowczykach, a także Żywocie, co potwierdza słuszność przekonania, iż z punktu widzenia perswazyjnej skuteczności zastosowaną taktykę obrończą wolno uznać za mało udaną, zwłaszcza że jej kruchość, słabe strony (obłudę) obnażała zwięźle zredagowana ówcześnie para trzynastozgłoskowców.

Jak bardzo boleśnie odczuwano społeczną dokuczliwość lisowczyków, świadczy determinacja władz siedemnastowiecznej Rzeczypospolitej, by obłożyć ich jedną z najbardziej bezwzględnych kar i to jeszcze w obliczu wciąż grożących ojczyźnie konfliktów militarnych, a postanowienie to (usankcjonowane konstytucją sejmową) oznaczało przecież dobrowolne pozbawienie polskiej armii niezwykle cennego wojskowo wsparcia. Nawet pomysł ich wysłania poza polskie granice w sukurs katolickiemu cesarstwu wzbudził u niektórych wątpliwości, okazał się chybiony, ponieważ przyczynił się do ściągnięcia na kraj rządzony akurat wtedy przez Zygmunta III Wazę (a króla z tego powodu oskarżano) nawały tureckiej (Tazbir 1987: 49-50). Nawiasem mówiąc, żołnierz swawolny to nie tylko przecież lisowczyk, dodajmy (Srogosz 2010). I ostatnie zdanie, a właściwie indagacja: ciekawe bowiem, kiedy powstały List do lisowczyków i O lisowskich i konfederackich żotnierzach, zresztą ich chronologiczne uwarunkowania m.in. skrupulatnie analizował J. Ziembiński (62-65); przed czy już po uchwaleniu „banda” na elearów - jeśli bowiem przed (a więc bez inspiracji wynikającej, powiedzmy cokolwiek z przymrużeniem oka, z mocy i urzędowej powagi parlamentarnego dokumentu), tym bardziej należałoby docenić literacki wysiłek autora bądź autorów wierszowanych recenzji. 


\section{Bibliografia}

Antologia literatury sowizdrzalskiej XVI i XVII wieku (1985). S. Grzeszczuk (wstęp i oprac.). Wyd. II zmienione. Wrocław: Zakład Narodowy im. Ossolińskich - Wydawnictwo.

BADECKI, K. (1950). Wstęp. W: Polska satyra mieszczańska. K. Badecki (oprac. i wstęp) (s. V-XLVIII). Kraków: Polska Akademia Umiejętności, Biblioteka Pisarzów Polskich, nr 91.

Bartoszewicz, J. (1881). Ksiadz Wojciech z Konojad Dembołęcki. W: tenże, Studia historyczne i literackie. K. Bartoszewicz (wyd.) (s. 90-112). Kraków: nakładem K. Bartoszewicza. Drukiem F.K. Pobudkiewicza w dzierżawie A. Koziańskiego, skład główny w Warszawie w księgarni Gebethnera i Wolffa. W Krakowie w księgarni F.K. Pobudkiewicza.

Buchwald-Pelcowa, P. (1995). Promocje i zakazy. Trudne drogi idei w ksiązkach w Polsce czasów baroku. W: Literatura polskiego baroku w kręgu idei. A. Nowicka-Jeżowa, M. Hanusiewicz, A. Karpiński (red.). Lublin: Wydawnictwo Katolickiego Uniwersytetu Lubelskiego.

Co nowego. Zbiór anegdot polskich z r. 1650 (1903). A. Brückner (wyd.) (s. 3-8; 9-107). Kraków: Akademia Umiejętności. Biblioteka Pisarzów Polskich, nr 48.

CzAPliński, W. (1966). O Polsce siedemnastowiecznej. Warszawa: Państwowy Instytut Wydawniczy.

DemboŁęcKi, W. (2005). Przewagi elearów polskich. R. Sztyber (wstęp i oprac.). Toruń: Wydawnictwo Adam Marszałek.

DzIEDuszycki, M. (1843-1844), Krótki rys dziejów i spraw lisowczyków, t. 1-2, Lwów: Zakład Naukowy im. Ossolińskich.

Ekes, J. (2010). Złota demokracja. Kraków: Ośrodek Myśli Politycznej.

Gloger Z. (1900). Encyklopedia staropolska ilustrowana. T. 1. Warszawa: druk P. Laskauera i W. Babickiego.

GrzeszczuK, S. (1985). Wstęp. W: Antologia literatury sowizdrzalskiej XVI i XVII wieku. S. Grzeszczuk, (wstęp i oprac.) (s. III-XCVII). Wyd. II zmienione. Wrocław: Zakład Narodowy im. Ossolińskich - Wydawnictwo.

GrzeszczuK, S. (1994). Błazeńskie zwierciadło. Rzecz o humorystyce sowizdrzalskiej XVI i XVII wieku. Wyd. II. Kraków: Universitas.

Hawrysz, M. (2012). Polemiczna twórczość Marcina Czechowica w perspektywie genologii lingwistycznej. Zielona Góra: Oficyna Wydawnicza Uniwersytetu Zielonogórskiego.

JANCZAK, Ł. (1906). Dembołęcki Wojciech z Konojad. W: Podręczna encyklopedia kościelna (s. 390-393). T. 7-8. Warszawa: Wydawnictwo Biblioteki Dzieł Chrześcijańskich.

Józef Bartłomiej Zimorowic. Utwory młodzieńcze (2016). R. Krzywy (oprac.). Warszawa: Wydawnictwo Sub Lupa.

KochańsKa, M. (1956). Ksiądz Wojciech Dembołęcki z Konojad. „Prace Literackie”. Zeszyty Naukowe Uniwersytetu Wrocławskiego. T. 1. Seria A, nr 2, s. 101-143.

KomudA, J. (2013). Samozwaniec. H. Czajkowski (i1.). T. 3. Lublin: Fabryka Słów.

KrólikowsKi, B. (1983). Szable nie rdzewiały, czyli przewagi lisowczyków nad Turkiem srogim pod Cecora i Chocimiem czynione. Warszawa: Wydawnictwo Ministerstwa Obrony Narodowej.

Krzywy, R. (2016). Wstęp. W: Józef Bartłomiej Zimorowic. Utwory młodzieńcze (2016). R. Krzywy (oprac.) (s. 5-45). Warszawa: Wydawnictwo Sub Lupa. 
List do lisowczyków (1965). W: Poeci polskiego baroku. J. Sokołowska i K. Żukowska (wstęp i oprac.) (s. 216). Warszawa: Państwowy Instytut Wydawniczy.

List o lisowczykach (2011). W: R. Sztyber. Wojciech Dembołęcki o lisowczykach wierszem i proza (1620-1621) (s. 211-222). Warszawa: Wydawnictwo DiG.

ŁozIŃski, W. (1904). Prawem i lewem. Obyczaje na Czerwonej Rusi w pierwszej połowie XVII wieku. T. 1: Czasy i ludzie. T. 2: Wojny prywatne. Wyd. II. Lwów: Księgarnia H. Altenberga.

Magnuszewski, W. (1962). Wiersze o lisowczykach. „Archiwum Literackie”. T. 4: Miscellanea staropolskie, s. 60-69.

Magnuszewski, W. (1972). Zapomniane lisowianum z 1621 roku. „Archiwum Literackie”. T. 16: Miscellanea staropolskie 4, s. 232-235.

Magnuszewski, W. (1976). Wokól kozaka Płachty. W: Z zagadnień historii literatury, L. Ludorowski (red.), Zielona Góra: Lubuskie Towarzystwo Naukowe.

Magnuszewski, W. (1978). Z dziejów elearów polskich. Stanisław Stroynowski - lisowski zagończyk, przywódca i legislator. WarszawaPoznań: Państwowe Wydawnictwo Naukowe.

Nędza z Bieda z Polski precz ida (1818). Kraków [b.d.] (w artykule powołano się na tę właśnie edycję z uwagi na odmiankę redakcyjną zabytku).

NowaK, Z. (1968). Kontrreformacyjna satyra obyczajowa w Polsce XVII wieku, Gdańsk: Gdańskie Towarzystwo Naukowe.

NowaK-DŁużEwski, J. (1971). Okolicznościowa poezja polityczna w Polsce. Zygmunt III, Warszawa: Instytut Wydawniczy PAX.

O lisowskich i konfederackich żotnierzach poeta (1963). W: W. N. Trepka. Liber generationis plebanorum (,Liber chamorum”). Cz. 1: wstępy wydawców i tekst. W. Dworzaczek, J. Bartyś, Z. Kuchowicz (wyd.), W. Dworzaczek (red.) (s. 22-23). Wrocław: Zakład Narodowy im. Ossolińskich.

Poeci polskiego baroku (1965). J. Sokołowska i K. Żukowska (wstęp i oprac.). Warszawa: Państwowy Instytut Wydawniczy.

Polska komedia rybałtowska (1931). K. Badecki (oprac. i wstęp). Lwów: Zakład Narodowy im. Ossolińskich.

SRogosz, T. (2010). Żołnierz swawolny. Z dziejów obyczajów armii koronnej w XVII wieku, Warszawa: Wydawnictwo DiG.

SzTyber, R. (2005). Piórem, kropidłem i szabla. Wojciecha Dembołęckiego pisarska i kapelańska przygoda z lisowczykami (1619-1623). Studia i szkice. Zielona Góra: Oficyna Wydawnicza Uniwersytetu Zielonogórskiego.

SzTYBer, R. (2011). Wojciech Dembołęcki o lisowczykach wierszem i proza (1620-1621). Warszawa: Wydawnictwo DiG.

SzTYBer, R. (2012). Wokół „Żywota kozaków lisowskich”. „Annales Universitatis Mariae Curie-Skłodowska. Sectio FF. Philologiae", vol. XXX, nr 1, s. 7-25.

SzTYBER, R. (2017). Jeszcze o „Żywocie kozaków lisowskich” (na marginesie reedycji pt. „Józef Bartłomiej Zimorowic. Utwory młodzieńcze”, oprac. R. Krzywy, Warszawa 2016). „Filologia Polska. Roczniki Naukowe Uniwersytetu Zielonogórskiego". R. 3, s. 320-337. TAzBIR, J. (1986). Szlaki kultury polskiej. Warszawa: Państwowy Instytut Wydawniczy. Tazbir, J. (1987). Polskie przedmurze chrześcijańskiej Europy. Mity a rzeczywistość historyczna, Warszawa: Wydawnictwo Interpress. 
TREPKA, W. N. (1963). Liber generationis plebeanorum (,Liber chamorum”). Cz. 1: wstępy wydawców i tekst. W. Dworzaczek, J. Bartyś, Z. Kuchowicz (wyd.), W. Dworzaczek (red.). Wrocław: Zakład Narodowy im. Ossolińskich.

Wiersze o lisowczykach (2011). W: R. Sztyber. Wojciech Dembołęcki o lisowczykach wierszem i proza (1620-1621) (s. 223-249). Warszawa: Wydawnictwo DiG.

Wisner H. (1995). Lisowczycy. Warszawa: Wydawnictwo Bellona, Oficyna Wydawnicza Rytm.

WojciechowsKa, M. (1927). Z dziejów książki w Poznaniu XVI w. Poznań: Księgarnia Uniwersytecka.

ZIEMBIŃSKI, J. (2009). O „Liście do lisowczyków” przypisywanym Olbrychtowi Karmanowskiemu. W: Sarmackie theatrum. IV. Studia o literaturze i ksiażce dawnej. R. Ocieczek i M. Jarczykowa (red.), Katowice: Wydawnictwo Uniwersytetu Śląskiego.

Żywot kozaków lisowskich (2016). W: Józef Bartłomiej Zimorowic. Utwory młodzieńcze. R. Krzywy (oprac.). Warszawa: Wydawnictwo Sub Lupa. 


\section{RadOSEAW SZTYber}

\section{ROGUE LITERATURE FEATURES OF THE LISOVCHICK PORTRAIT IN OUTPUT FROM 1620 (RECEPTION-INTERPRETATIVE DILEMMAS)}

The sketch is an attempt of a discussion on three pieces of poetry, i.e. List o lisowczykach [Letter on Lisovchicks], Wiersze o lisowczykach [Verses on Lisovchicks] and Żywot kozaków lisowskich [Life of Lisovski Cossacks] including their title protagonists' characteristics in which typical for rogue literature means of expression dominate. In each of the aforementioned text a reader may meet comical or parody approaches, there is no lack of irony, caricature and grotesque, either. Nevertheless, jokes do not always appear to be accurate for some of them are crude and heavy - series of the jests was supposed to present a Lisovchick in a good light at least, however, such a decision seem to be rather surprising because - according to persuasive assumptions of the studied written relics - particularly humour should have justified or should have allow to be accustomed anyway to adventurousness, lawlessness and plunder associated almost proverbially with the Lisovchicks' daily habits but their undisputed military skills are here left in silence although they were also described in the poems. In brief, the idea is quite risky and possibly pointless, despite texts' conditions logics, the rhymed statements' contents, the idea proves favour for the self-styled mercenaries portrayed. The complexity arise many doubts resulting in some kind of interpretative dilemmas. An author or authors of two else rhymed short poems (List do lisowczyków [Letter to Lisovchicks] and O lisowskich i konfederackich żotnierzach [On Lisowski and confederate soldiers] both hypothetically attributed to Olbrycht Karmanowski) experienced them, too. The last one seems to be not only a reprimand formulated in connection with an attitude of the mercenary regiment because above all it unmasks and condemns ways of literary misrepresenting authentic pathologies which became common advantages in Żywot kozaków lisowskich thanks to unusual peculiarities of the world turned upside down (in rogue literature manner). That is why O lisowskich $i$ konfederackich żołnierzach may be considered as a type of a literary review. Almost the same according to List do lisowczyków, its author reveals transparently criticism towards the addressees of his own "post", nonetheless a group of various allusions, crypto-quotes or other references let one believe that the poem is a polemics against List, Wiersze o lisowczykach and Żywot and for the reason the text also gains review properties. The two poems ascribed to Karmanowski are correlated for some mutual similarities like e.g. their concept or identical metrical line (Polish alexandrine), moreover both of them may be treated as evidences of early reception of the three shortly discussed apologetic lisovianas' which — in spite of their author(s) intentions - did not reach designated aims and did not contribute to restore a good name of the military unit founded by Józef Aleksander Lisowski. 